\title{
SIMULASI COMPUTATIONAL FLUID DYNAMIC (CFD) PADA RUANGAN DRIVER MOBIL TIM HORAS UNTUK MEMPREDIKSI KENYAMANAN TERMAL PENGEMUDI
}

\author{
Amma Muliya R. ${ }^{1}$, Himsar Ambarita ${ }^{2}$, A. Halim Nasution ${ }^{3}$, Mulfi Hazwi ${ }^{4}$, Syahril Gultom ${ }^{5}$ \\ 1,2,3,4,5 Departemen Teknik Mesin, Fakultas Teknik, Universitas Sumatera Utara \\ Jl. Almamater, Kampus USU Medan 20155 \\ E-mail : smartams13@gmail.com
}

\begin{abstract}
ABSTRAK
Kenyamanan termal (thermal comfort) merupakan salah satu aspek yang harus dipertimbangkan ketika akan mendesign suatu ruangan driver pada sebuah mobil. Penelitian ini berfokus pada simulasi Computational Fluid Dynamic (CFD) ruangan driver mobil Tim Horas Universitas Sumatera Utara generasi keempat untuk memprediksi kenyamanan termal pengemudi. Simulasi dilakukan selama 30 menit dan hasil yang diperoleh adalah temperatur pada 16 titik tubuh pengemudi. Selanjutnya hasil simulasi dibandingkan dengan standar zona kenyamanan yang telah ditetapkan untuk tubuh manusia. Dari hasil simulasi, persentase kenyamanan tertinggi didapatkan pada menit ke-12 dengan nilai $31,25 \%$ (5 titik nyaman). Nilai dari kelima titik tersebut adalah tangan kiri $\left(29,367^{\circ} \mathrm{C}\right)$, betis kiri $\left(27,3639^{\circ} \mathrm{C}\right)$, betis kanan $\left(28^{\circ} \mathrm{C}\right)$, kaki kiri $\left(27^{\circ} \mathrm{C}\right)$, dan kaki kanan $\left(27^{\circ} \mathrm{C}\right)$. Persentase kenyamanan terendah didapatkan pada menit ke- 15 dengan nilai $0 \%$ (tidak ada titik nyaman). Persentase rata-rata kenyamanan termal pengemudi pada ruangan driver mobil Tim Horas generasi keempat selama 30 menit adalah 13,75\%.
\end{abstract}

Kata Kunci: Kenyamanan Termal, CFD , Ruangan Driver, Temperatur, Persentase rata-rata kenyamanan termal

\section{PENDAHULUAN}

Konsumsi energi di sektor transportasi dari tahun ke tahun telah meningkat secara signifikan, sehingga diperlukan upaya untuk mendapatkan sistem transportasi yang hemat energi. Dalam menyanggupi tantangan itu sebuah kompetisi Shell Ecomarathon (SEM) Asia dan Indonesia Energy Marathon Challenge (IEMC) menjadi ajang bagi mahasiswa untuk berinovasi dalam mendesain, membuat, dan menjalankan mobil hemat energi sehingga didapatkan konsumsi bahan bakar terbaik. Tim Horas Universitas Sumatera Utara sampai saat ini telah membuat mobil generasi pertama sampai keempat yang dipersiapkan untuk mengikuti kedua perlombaan tersebut.

Salah satu parameter yang dipertimbangkan dalam pembuatan mobil Tim Horas yaitu desain interior pada ruangan driver yang berpengaruh terhadap kenyamanan termal driver dalam mengemudi. Untuk mengetahui distribusi temperatur pada ruangan driver (driver compartment) dapat digunakan software ANSYS FLUENT sehingga bisa diprediksi aliran fluida yang terjadi pada ruangan driver mobil Tim Horas. Dengan metode simulasi Computational Fluid Dynamic (CFD) menggunakan software ANSYS FLUENT, dapat diketahui temperatur di setiap titik pada ruangan driver yang berpengaruh terhadap kenyamanan termal pengemudi. Permasalahan yang diangkat dalam penelitian ini adalah bagaimana pengaruh temperatur yang ada di ruangan driver mobil Tim Horas generasi keempat terhadap kenyamanan termal (thermal comfort) pengemudi. 


\section{TINJAUAN PUSTAKA Kenyamanan Termal}

ASHRAE [1] mendefinisikan kenyamanan termal sebagai suatu pemikiran dimana kepuasan didapati. Meskipun digunakan untuk mengartikan tanggapan tubuh, kenyamanan termal merupakan kepuasan yang dialami oleh manusia yang menerima suatu keadaan termal, keadaan ini alami baik secara sadar ataupun tidak sadar. Pemikiran suhu netral atau suhu tertentu yang sesuai untuk seseorang dinilai agak kurang tepat karena nilai kenyamanan bukan merupakan nilai yang pasti dan selalu berbeda bagi setiap individu.

\section{Standar Kenyamanan Termal Pada Tubuh manusia}

Perbandingan hasil pengukuran dengan standar kenyamanan thermal dapat diketahui dari beberapa parameter, yaitu:

1. Kecepatan udara

Georg Lippsmeier [2] menyatakan bahwa patokan untuk kecepatan angin ialah:

- $0,25 \mathrm{~m} / \mathrm{s}$ ialah nyaman, tanpa dirasakan adanya gerakan udara.

- $0,25-0,5 \mathrm{~m} / \mathrm{s}$ ialah nyaman, gerakan udara terasa.

- 1,0-1,5 m/s aliran udara ringan sampai tidak menyenangkan.

- Diatas $1,5 \mathrm{~m} / \mathrm{s}$ tidak menyenangkan.

2. Suhu

Suhu merupakan salah satu parameter yang menentukan kenya-manan seseorang. Suhu memiliki hubungan yang erat terhadap sensasi, psikologi, dan kesehatan tubuh manusia. Suhu kenyamanan termal menurut skala new effective temperature [3] serta hubungannya dengan reaksi psikologi dan kesehatan manusia bisa dilihat pada gambar 1 .

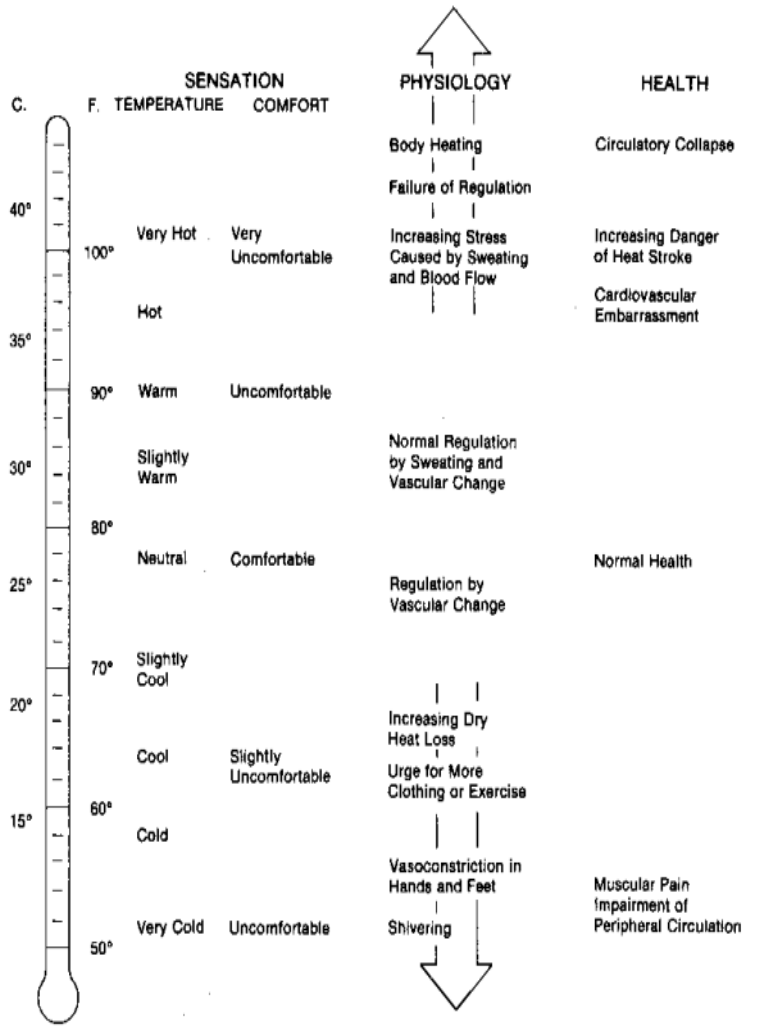

Gambar 1. Skala termal ET* serta hubungan terhadap reaksi psikologi dan kesehatan pada tubuh manusia [3] 
Sesuai standard ASHRAE 55-1992 [4] and ISO 7730 [5], Equivalent Homogenous Tempe- rature (EHT) untuk tubuh manusia dapat digunakan sebagai standar kenyamanan termal. Bohm [6] menjelaskan dalam jurnalnya, terdapat 16 segmen titik pada tubuh manusia yang bisa dijadikan acuan untuk menentukan kenyamanan termal. Gambar 2 memperlihatkan standar zona kenyamanan termal tubuh manusia.

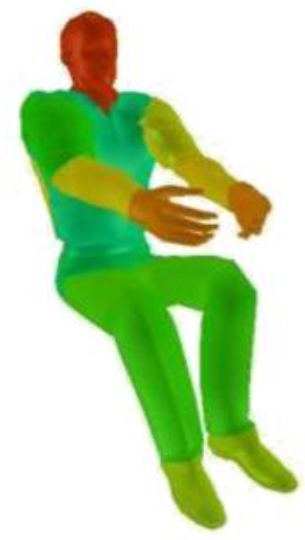

\section{Standar Kenyamanan Termal Tubuh Manusia}

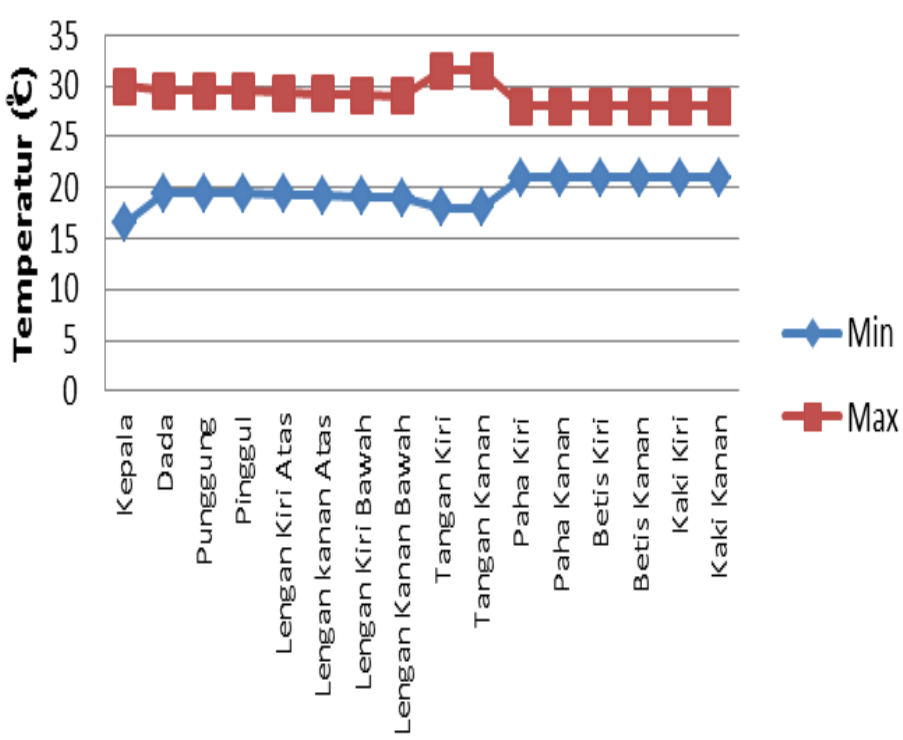

Gambar 2. EHT indeks untuk 16 titik pada tubuh manusia [6] 
Untuk nilai temperatur zona nyaman pada 16 titik tubuh manusia diperlihatkan pada tabel 1 .

Tabel 1. Nilai temperatur minimum dan maksimum zona kenyamanan termal pada 16 titik tubuh manusia [6]

\begin{tabular}{|l|c|c|c|c|}
\hline \multirow{2}{*}{ Bagian Tubuh } & \multicolumn{2}{|c|}{$\begin{array}{r}\text { Temperatur Zona } \\
\text { Nyaman ('K) }\end{array}$} & \multicolumn{2}{c|}{$\begin{array}{c}\text { Temperatur Zona } \\
\text { Nyaman }\left({ }^{\circ} \text { C) }\right.\end{array}$} \\
\cline { 2 - 5 } & Min & Max & Min & Max \\
\hline Kepala & 289,5 & 303 & 16,5 & 30 \\
\hline Dada & 292,5 & 302,5 & 19,5 & 29,5 \\
\hline Punggung & 292,5 & 302,5 & 19,5 & 29,5 \\
\hline Pinggul & 292,5 & 302,5 & 19,5 & 29,5 \\
\hline Lengan Kiri Atas & 292,3 & 302,3 & 19,3 & 29,3 \\
\hline Lengankanan Atas & 292,2 & 302,2 & 19,2 & 29,2 \\
\hline Lengan Kiri Bawah & 292,1 & 302,1 & 19,1 & 29,1 \\
\hline Lengan Kanan Bawah & 292 & 302 & 19 & 29 \\
\hline Tangan Kiri & 291 & 304,5 & 18 & 31,5 \\
\hline Tangan Kanan & 291 & 304,5 & 18 & 31,5 \\
\hline Paha Kiri & 294 & 301 & 21 & 28 \\
\hline Paha Kanan & 294 & 301 & 21 & 28 \\
\hline Betis Kiri & 294 & 301 & 21 & 28 \\
\hline Betis Kanan & 294 & 301 & 21 & 28 \\
\hline Kaki Kiri & 294 & 301 & 21 & 28 \\
\hline Kaki Kanan & 294 & 301 & 21 & 28 \\
\hline
\end{tabular}

\section{Perhitungan Dinamika Fluida (Computational Fluid Dyna-mics)}

Dinamika fluida [7] adalah cabang dari ilmu mekanika fluida yang mempelajari tentang pergerakan fluida. Dinamika fluida dipelajari melalui tiga cara yaitu:

- Dinamika fluida eksperimental

- Dinamika fluida secara teori, dan

- Dinamika fluida secara numerik (CFD)

Computational Fluid Dynamics (CFD) adalah suatu cabang dari mekanika fluida yang menggunakan metode numerik untuk menyelesaikan dan menganalisa elemenelemen yang akan disimulasikan. Pada proses ini, computer diminta untuk menyelesaikan perhitungan-perhitungan numerik dengan cepat dan akurat. Prinsip kerja pada CFD adalah model yang akan kita simulasikan berisi fluida akan dibagi menjadi beberapa bagian atau elemen. Elemen-elemen yang terbagi tersebut merupakan sebuah kontrol perhitungan yang akan dilakukan oleh software selanjutnya elemen diberi batasan domain dan boundary condition. Prinsip inilah yang banyak digunakan pada proses perhitungan dengan menggunakan bantuan komputasi.

\section{Metode CFD Menggunakan Perangkat Lunak FLUENT}

CFD memungkinkan penye-lesaian persamaan pembentuk aliran dengan menggunakan suatu perhitungan numerik yang disebut dengan metode volume hingga (finite volume methods). Untuk memudahkan perhitungan numerik, telah 
tersedia banyak perangkat lunak computer. Salah satu perangkat lunak yang terkenal dalam perhitungan dan simulasi CFD adalah FLUENT.

FLUENT [8] adalah program komputer yang dikembangkan oleh ANSYS Inc. untuk memodelkan aliran fluida dan perpindahan panas dalam geometri yang kompleks. FLUENT merupakan salah satu jenis program CFD (Computational Fluid Dynamics) yang menggunakan metode diskritisasi volume hingga. FLUENT memiliki fleksibilitas mesh, sehingga kasus-kasus aliran fluida yang memiliki mesh tidak terstruktur akibat geometri benda yang rumit dapat diselesikan dengan mudah.

\section{METODOLOGI PENELITIAN}

Diagram Alir Penelitian dan Simulasi gambar 3.

Diagram alir yang digunakan dalam penelitian dan simulasi dapat dilihat pada

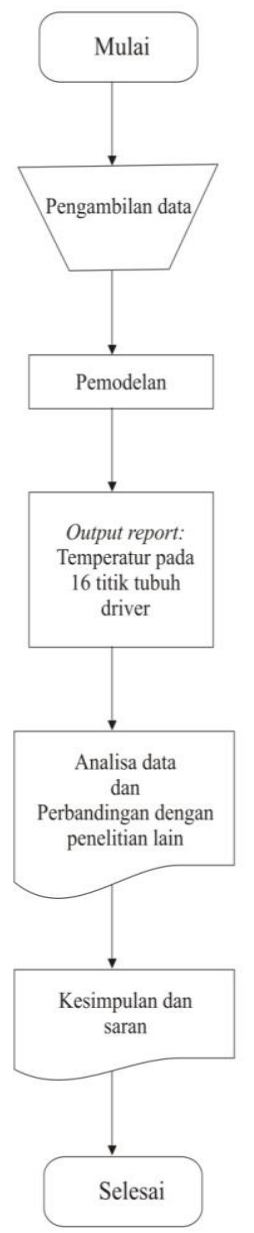

(a)

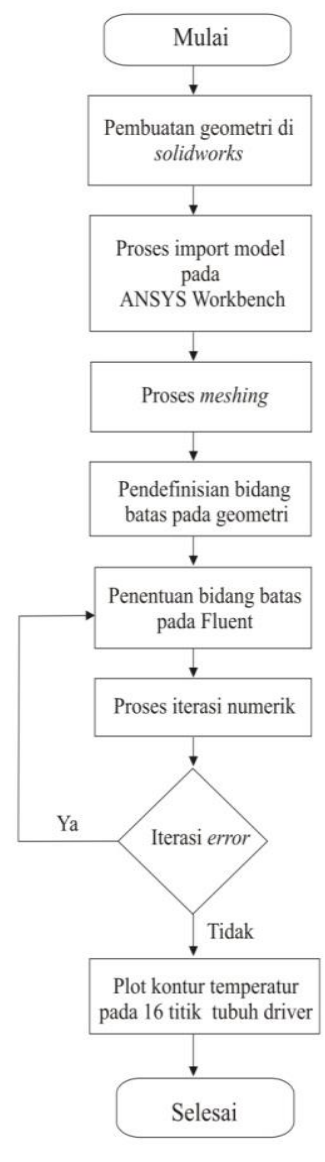

(b)

\section{(a) Penelitian,}

Gambar 3. Diagram alir

(b) Simulasi

Diagram alir penelitian meliputi pengambilan data, pemodelan, hasil temperatur yang didapat dari 16 titik tubuh, analisa dan perbandingan dengan penelitian lain, dan yang terakhir kesimpulan serta saran.

Sedangkan diagram alir simulasi meliputi pembuatan geometri ruangan driver dengan solidworks, proses import model pada ANSYS Work-bench, proses meshing, 
pendefinisi-an bidang batas pada geometri, penentuan bidang batas pada FLUENT, proses iterasi numerik, dan plot kontur temperatur pada 16 titik tubuh driver.

\section{Proses Pre-Processing}

Proses pre-processing meru-pakan proses yang dilakukan sebelum pengujian (simulasi). Proses ini mencakup pembuatan model (gambar 4), penentuan domain (gambar 5) dan pembuatan mesh (gambar 6).

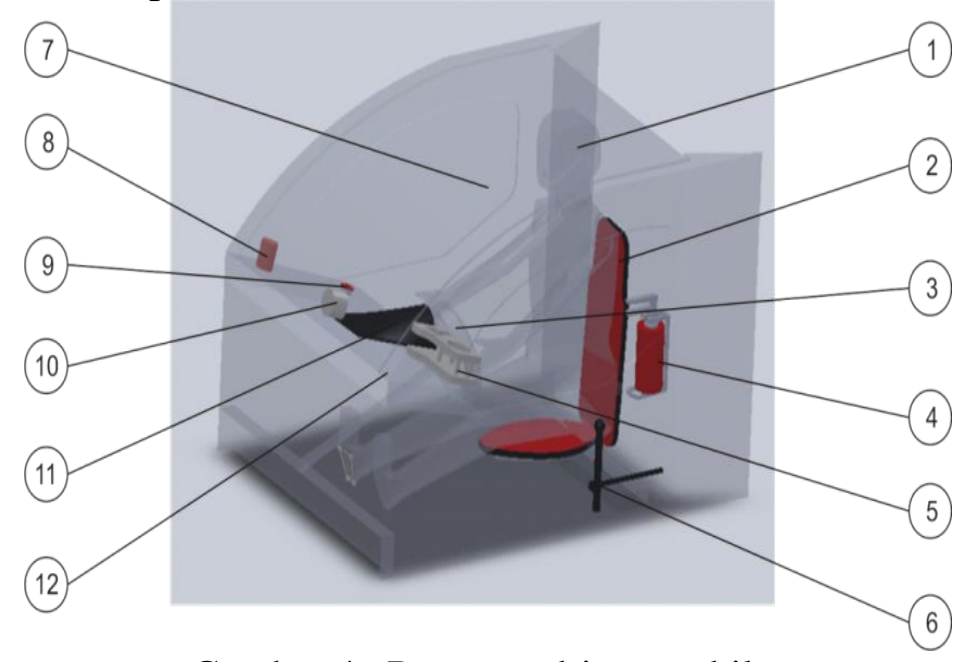

Gambar 4. Ruangan driver mobil

Tim Horas generasi keempat

Keterangan gambar:

1. Driver

2. Tempat duduk

3. Stir

4. Pemadam api

5. Tempat botol minum

6. Pengubah gigi

7. Ruangan driver

8. Minyak rem

9. Emergency Shutdown

10. RPM meter

11. Gear indicator

12. Dashboard

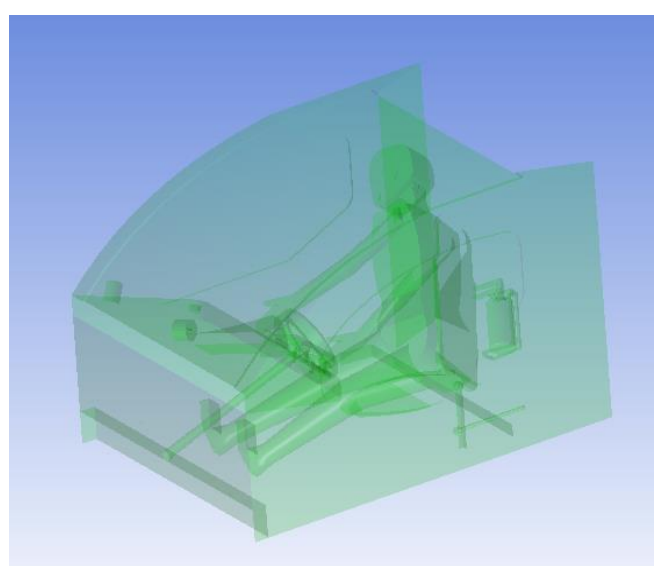

Gambar 5. Computational Domain 


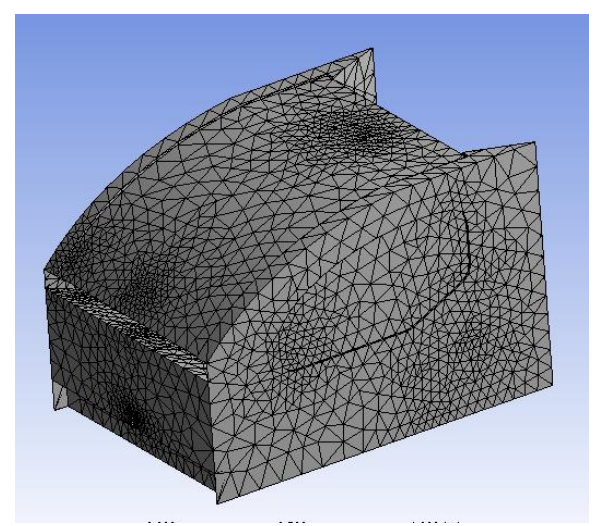

(a)

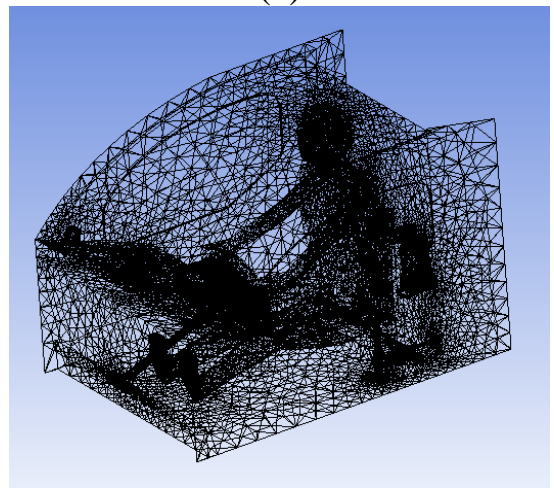

(b)

Gambar 6. Bentuk mesh default

(a) Bentuk mesh tampak luar,

(b) Bentuk mesh secara transparan

\section{Pengaturan Simulasi (Simulation Setting)}

Pengaturan simulasi yang dimaksud adalah menetukan beberapa aspek yang diperlukan dalam simulasi seperti bentuk solver yang dipilih, material fluida, jenis viskos, dll sesuai dengan asumsi yang dilakukan. Tabel 2 dan 3 menunjukkan pengaturan simulasi yang dilakukan di dalam FLUENT. Sedangkan titik tubuh yang diukur pada driver diperlihatkan pada gambar 7 .

Tabel 2. Parameter dan Asumsi yang Digunakan dalam Simulasi CFD 


\begin{tabular}{|l|l|l|}
\hline No & Parameter & Keterangan \\
\hline 1. & Parameter tetap & \\
\hline & Kecepatan udara (inlet) & $30 \mathrm{Km} / \mathrm{h}$ \\
\hline & Temperatur lingkungan & $31,35^{\circ} \mathrm{C}$ \\
\hline & Massa jenis udara & $\rho=1,225 \mathrm{Kg} / \mathrm{m}^{3}$ \\
\hline & Tekanan operasional & $101325 \mathrm{~Pa}$ \\
\hline & Radiasi matahari & Qrad $=147,5 \mathrm{~W} / \mathrm{m}^{2}$. \\
\hline 2. & Kondisi batas & \\
\hline & Inlet & Velocity inlet \\
\hline & Outlet & Outflow \\
\hline & Driver & Wall \\
\hline & Body mobil & Wall \\
\hline & Kaca mobil & Wall \\
\hline & Alas bawah & Wall \\
\hline & Aksesoris lainnya & Symmetri \\
\hline 3. & Lama waktu simulasi & 30 menit $(1800 \mathrm{~s})$ \\
\hline
\end{tabular}

Tabel 3. Pengaturan simulasi pada

FLUENT

\begin{tabular}{|c|c|}
\hline Aspek & Pengaturan \\
\hline Model Solver (Solver Model) & Pressure based, 3D, Transient \\
\hline Model Energi (Energy Model) & On \\
\hline Model Viskos (Viscous Model) & Turowlent Spalart-Allmaras \\
\hline Model Radiasi (Radiation Model) & Surface to Surface (S2S) \\
\hline Materials & $\begin{array}{l}\text { Fluid: Air with constant density, } \\
\rho=1,225 \mathrm{Kg} / \mathrm{m}^{3} \\
\text { Solid: acrylic, fberglass, dan seng. [18] }\end{array}$ \\
\hline Kondisi Operasi (Operating Condition) & $101325 \mathrm{~Pa}$ \\
\hline Surface monitor & $\begin{array}{l}16 \text { titik tubuh driver (gambar 3.11): } \\
\text { Vertex average, Static temperature }\end{array}$ \\
\hline Inisiasi (Initialize) & Velocity Inlet \\
\hline
\end{tabular}

Gambar 7. Titik tubuh yang diukur pada driver 
Keterangan gambar:

1. Kepala

2. Dada

3. Lengan kiri atas

4. Lengan kiri bawah

5. Tangan kiri

6. Paha kiri

7. Betis kiri

8. Kaki kiri

9. Punggung

10. Lengan kanan atas

11. Lengan kanan bawah

12. Tangan kanan

13. Pinggul

14. Paha kanan

15. Betis kanan

16. Kaki kanan

\section{HASIL DAN PEMBAHASAN}

Pada gambar 8 akan ditampil-kan gambar kontur statik temperatur tubuh driver yang didapat dari hasil simulasi selama 30 menit (1800 s) .

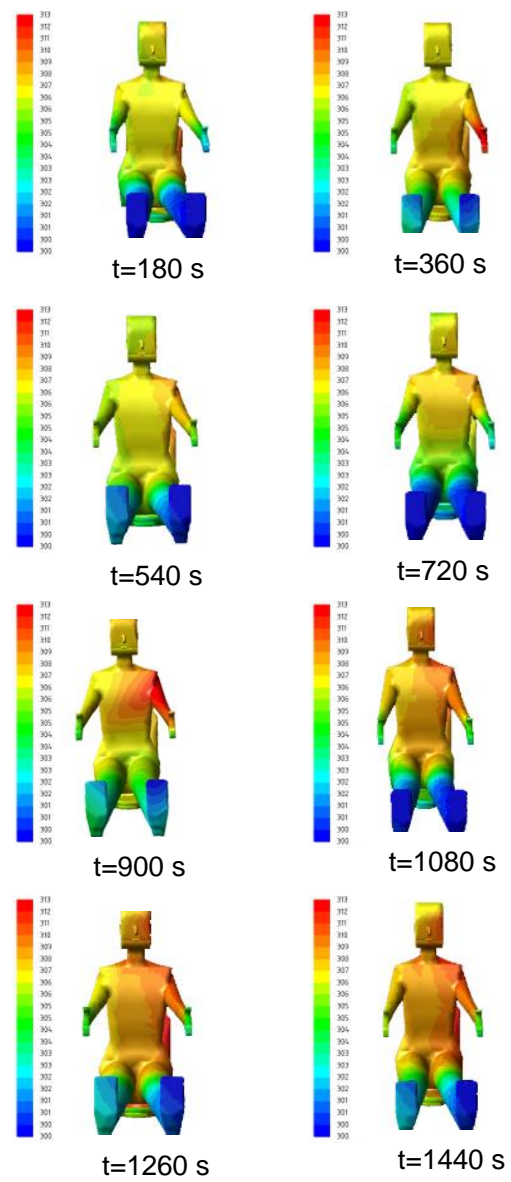



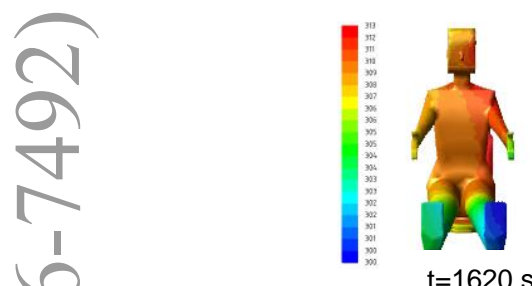

$\mathrm{t}=1620 \mathrm{~s}$

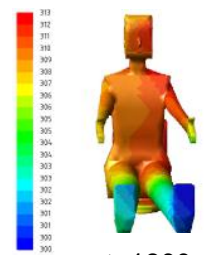

$\mathrm{t}=1800 \mathrm{~s}$

Gambar 8. Kontur temperatur selama 30 menit.

Grafik kenyamanan termal driver selama 30 menit (1800 s) dapat dilihat pada gambar $9 \mathrm{~s} / \mathrm{d} 18$.

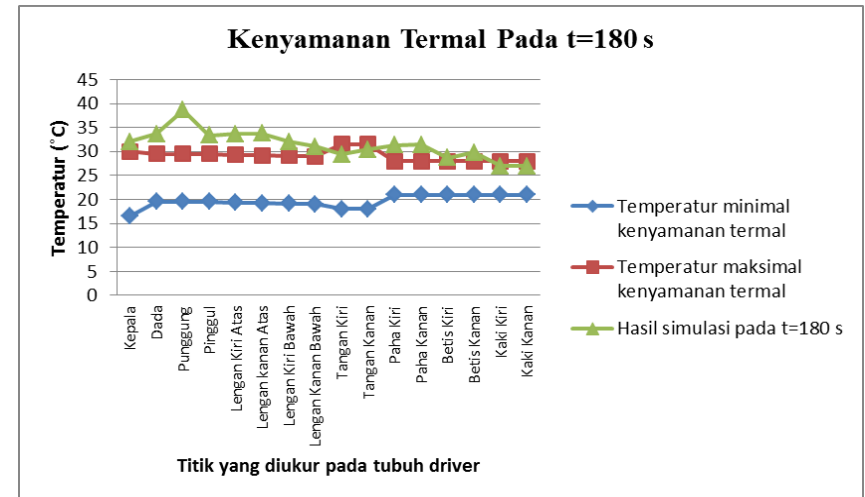

Gambar 9. Grafik temperatur kenyamanan termal pada menit ke-3 (180 s)

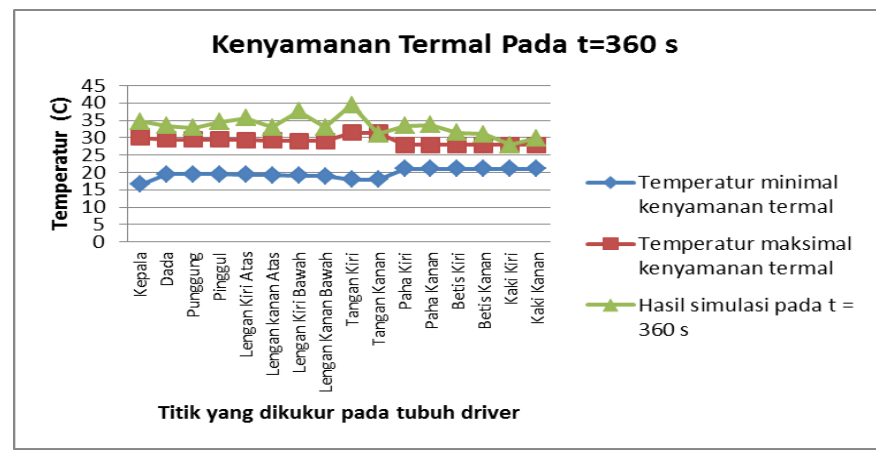

Gambar 10. Grafik temperatur kenyamanan termal pada menit ke-6 (360 s)

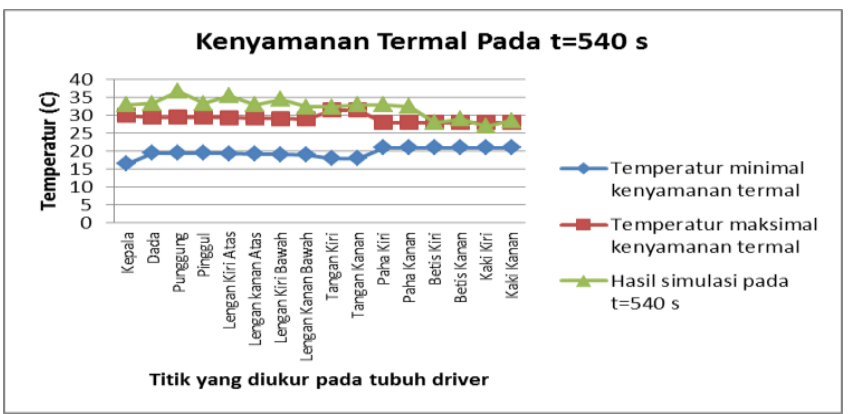

Gambar 11. Grafik temperatur kenyamanan termal pada menit ke-9 (540 s) 


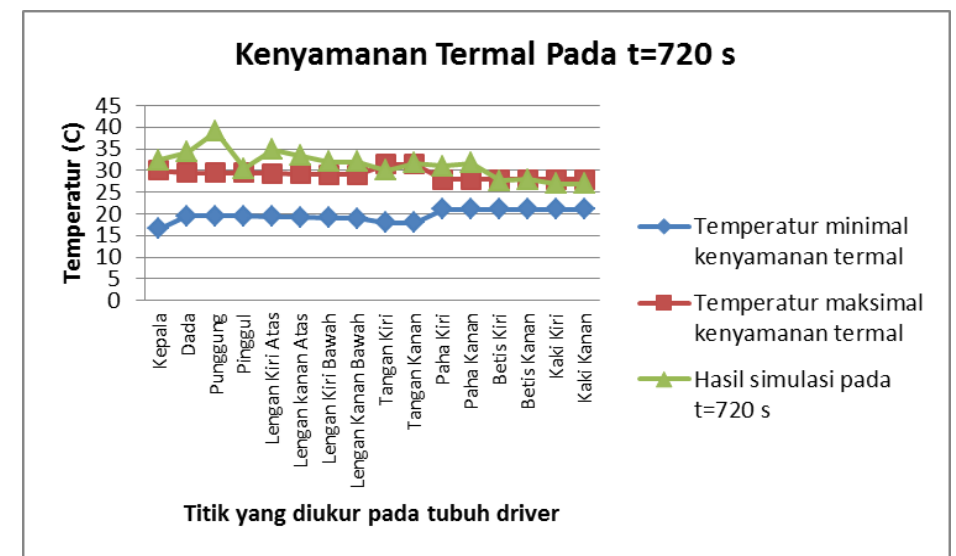

Gambar 12. Grafik temperatur kenyamanan termal pada menit ke-12 (720 s)

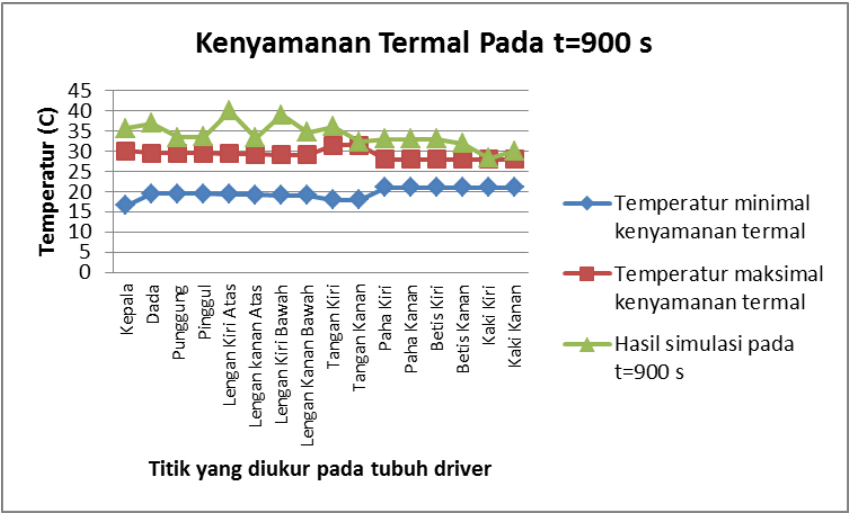

Gambar 13. Grafik temperatur kenyamanan termal pada menit ke-15 (900 s)

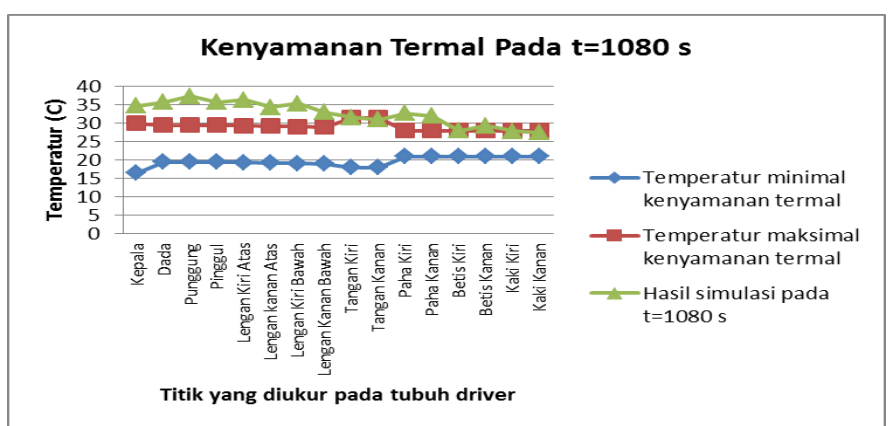

Gambar 14. Grafik temperatur kenyamanan termal pada menit ke-18 (1080 s)

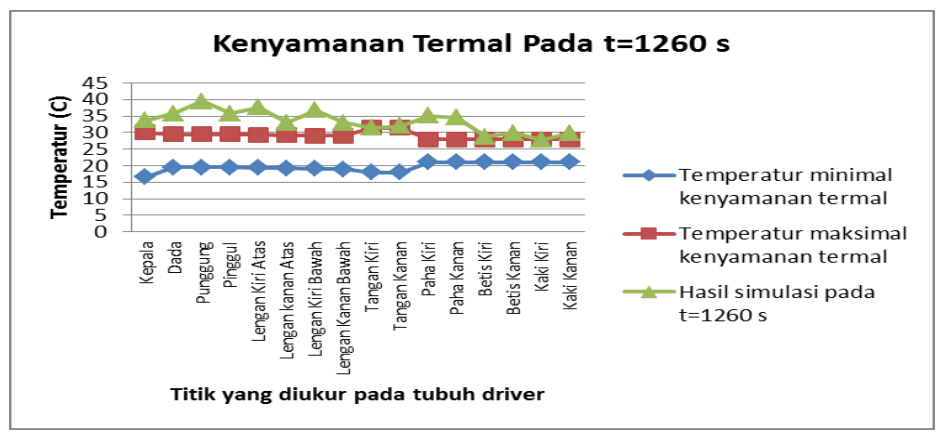

Gambar 15. Grafik temperatur kenyamanan termal pada menit ke-21 (1260 s) 


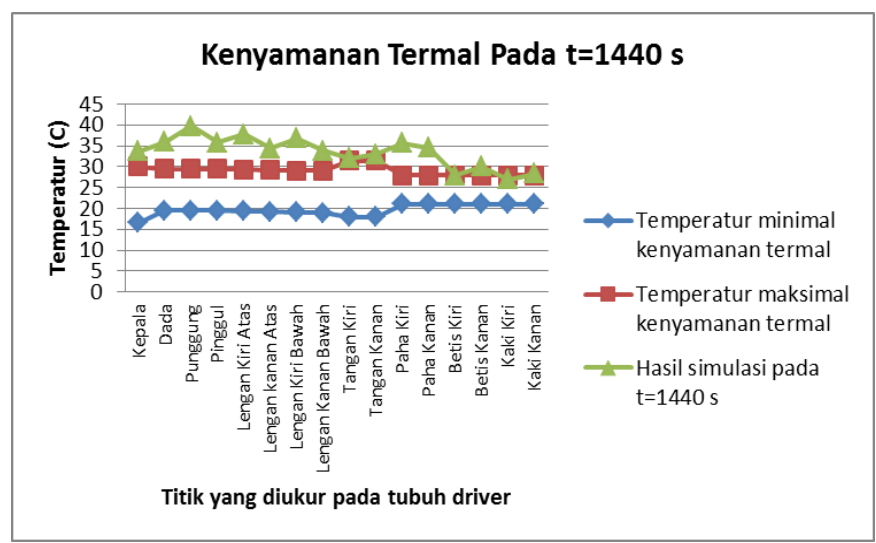

Gambar 16. Grafik temperatur kenyamanan termal pada menit ke-24 (1440 s)

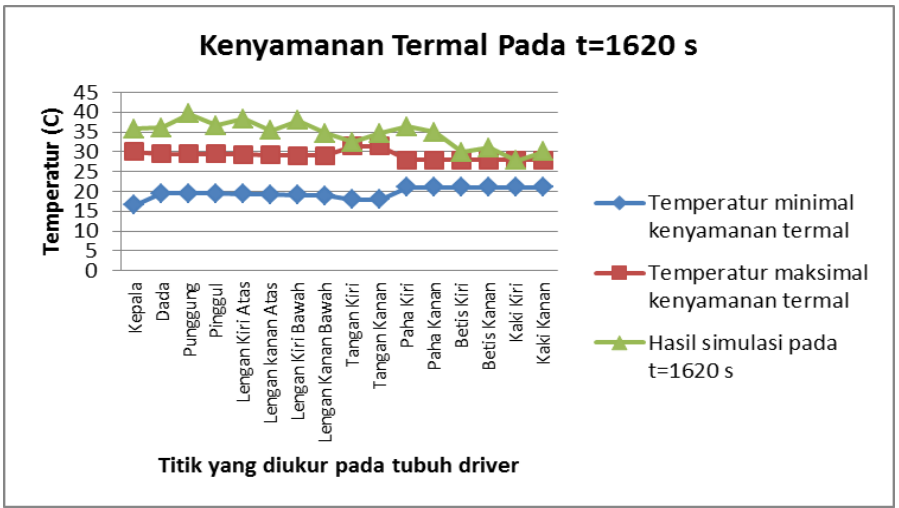

Gambar 17. Grafik temperatur kenyamanan termal pada menit ke-27 (1620 s)

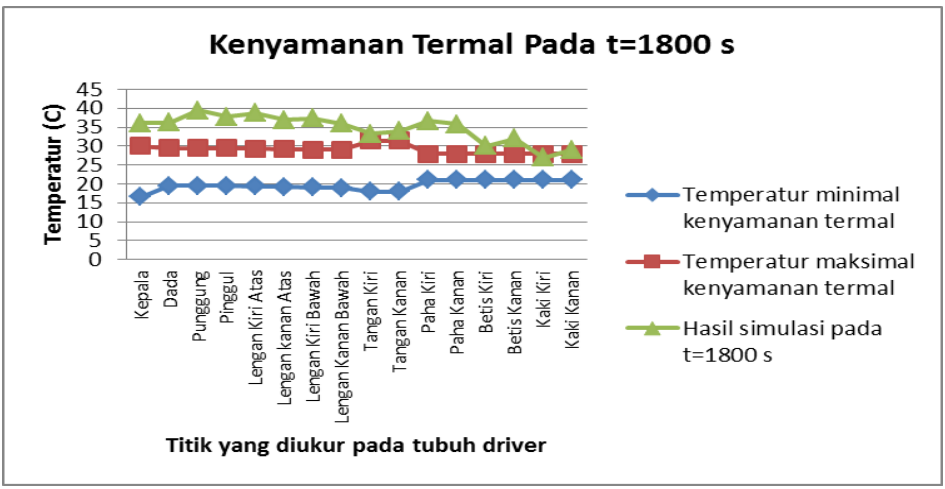

Gambar 18. Grafik temperatur kenyamanan termal pada menit ke-30 (1800 s)

Dari grafik pada gambar $9 \mathrm{~s} / \mathrm{d}$ 18, dapat dilihat persentase kenyamanan tertinggi didapatkan pada menit ke-12 dengan nilai 31,25\% (5 titik nyaman). Nilai dari kelima titik tersebut adalah tangan kiri $\left(29,367^{\circ} \mathrm{C}\right)$, betis kiri $\left(27,3639^{\circ} \mathrm{C}\right)$, betis kanan $(28$ $\left.{ }^{\circ} \mathrm{C}\right)$, kaki kiri $\left(27^{\circ} \mathrm{C}\right)$, dan kaki kanan $\left(27^{\circ} \mathrm{C}\right)$. Sedangkan persentase kenyamanan terendah didapatkan pada menit ke-15 dengan nilai $0 \%$ (tidak ada titik nyaman).

Setelah mengetahui persen kenyamanan termal dari menit ke-3 sampai menit ke30, pada tabel 4 ditampilkan persen rata-rata kenyamanan termal ruangan driver mobil Tim Horas generasi keempat selama 30 menit.

Tabel 4. Persentase rata-rata kenya-manan termal selama 30 menit 


\begin{tabular}{|c|c|c|}
\hline No & Menit ke (menit) & Kenyamanan termal (\%) \\
\hline 1 & 3 & 25 \\
\hline 2 & 6 & 12,5 \\
\hline 3 & 9 & 12,5 \\
\hline 4 & 12 & 31,25 \\
\hline 5 & 15 & 0 \\
\hline 6 & 18 & 25 \\
\hline 7 & 21 & 6,25 \\
\hline 8 & 24 & 12,5 \\
\hline 9 & 27 & 6,25 \\
\hline 10 & 30 & 6,25 \\
\hline \multicolumn{2}{|c|}{ Persentase rata-rata } & $\mathbf{1 3 , 7 5}$ \\
\hline
\end{tabular}

Dari tabel 4 dapat dilihat bahwa persentase rata-rata kenyamanan termal ruangan driver mobil Tim Horas generasi keempat selama 30 menit masih sangat rendah, yaitu $13,75 \%$. Ini menunjukkan bahwa ruangan driver mobil Tim horas generasi keempat belum bisa dikatakan nyaman karena masih jauh dari standar kenyamanan.

\section{KESIMPULAN}

Berdasarkan hasil dan pembahasan dapat ditarik kesimpulan sebagai berikut:

1. Metode Computational Fluid Dynamic (CFD) dapat memprediksi dengan efisien dan efektif pada ruangan driver mobil Tim horas generasi keempat sehingga bisa mengetahui kenyamanan termal pengemudi.

2. Persentase kenyamanan tertinggi didapatkan pada menit ke-12 dengan nilai 31,25 $\%$ (5 titik nyaman). Nilai dari kelima titik tersebut adalah tangan kiri $\left(29,367^{\circ} \mathrm{C}\right)$, betis kiri $\left(27,3639^{\circ} \mathrm{C}\right)$, betis kanan $\left(28{ }^{\circ} \mathrm{C}\right)$, kaki kiri $\left(27^{\circ} \mathrm{C}\right)$, dan kaki kanan $\left(27^{\circ} \mathrm{C}\right)$.

3. Persentase kenyamanan terendah didapatkan pada menit ke-15 dengan nilai $0 \%$ (tidak ada titik nyaman).

4. Persentase rata-rata kenyamanan termal pengemudi pada ruangan driver mobil Tim Horas generasi keempat selama 30 menit adalah 13,75\%.

\section{DAFTAR PUSTAKA}

[1] De Dear\& Brager. 2002. Thermal Comfort in Naturally Ventilated Buildings: Revisions to ASHRAE Standard 55. Jurnal: Energy and Buildings 34.

[2] Lippsmeir, G. 1994. Bangunan Tropis. Jakarta: Erlangga.

[3] McDowall, Robert . 2006. Fundamentals of HVAC Systems. USA: ASHRA elearning.

[4] ASHRAE. 1992. Thermal environmental conditions for human occupancy. ANSI/ASHRAE Standard 55-1992. Atlanta: American Society of Heating, Refrigerating, and Air-Conditioning Engineers, Inc.

[5] ISO. 1994. Moderate thermal environments-determination of the PMV and PPD indices and specification of the conditions for thermal comfort. International Standard 7730. Geneva: International Standards Organization.

[6] M. Bohm M., et al. 1990 . Evaluation of Vehicle Climate with a Thermal Manikin - The Relationship between Human Temperature Experience and Local Heat Loss. Swedish Institute of Agricultural Enginee. ring. JTI-Report 123.

[7] Tuakia, Firman. 2008. Dasar-dasar CFD Menggunakan Fluent. Bandung: Informatika Bandung.

[8] Ansys Inc. Ansys Fluent Documentation. Ansys Inc 


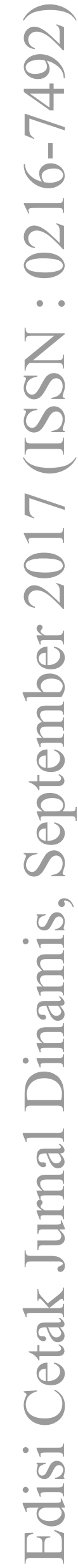

